\title{
The length of the dry season may be associated with leaf scleromorphism in cerrado plants
}

\author{
MARCELO C. SOUZA ${ }^{1}$, AUGUSTO C. FRANCO ${ }^{2}$, \\ MUNDAYATAN HARIDASAN ${ }^{3}$, DAVI R. ROSSATTO ${ }^{4}$, JANAÍNA F. DE ARAÚJO ${ }^{3}$, \\ LEONOR P.C. MORELLATO ${ }^{5}$ and GUSTAVO HABERMANN ${ }^{5}$ \\ ${ }^{1}$ Programa de Pós-Graduação em Ciências Biológicas (Biologia Vegetal), \\ Departamento de Botânica, Instituto de Biociências, UNESP, \\ Avenida 24 A, 1515, Bela Vista, 13506-900 Rio Claro, SP, Brasil \\ ${ }^{2}$ Departamento de Botânica, Instituto de Ciências Biológicas, Universidade de Brasília, \\ Campus Universitário Darcy Ribeiro, 70904-970 Brasília, DF, Brasil \\ ${ }^{3}$ Departamento de Ecologia, Instituto de Ciências Biológicas, Universidade de Brasília, \\ Campus Universitário Darcy Ribeiro, 70904-970 Brasília, DF, Brasil \\ ${ }^{4}$ Departamento de Biologia Aplicada à Agropecuária, Faculdade de \\ Ciências Agrárias e Veterinárias, UNESP, Via de Acesso \\ Prof. Paulo Donato Castellane, s/n, 14884-900 Jaboticabal, SP, Brasil \\ ${ }^{5}$ Departamento de Botânica, Instituto de Biociências, UNESP, \\ Avenida 24 A, 1515, Bela Vista, 13506-900 Rio Claro, SP, Brasil
}

Manuscript received on July 21, 2014; accepted for publication on December 5, 2014

\begin{abstract}
Despite limitations of low fertility and high acidity of the soils, the cerrado flora is the richest amongst savannas. Many cerrado woody species show sclerophyllous leaves, which might be related to the availability of water and nutrients in the soil. To better understand the function and structure of cerrado vegetation within its own variations, we compared two cerrado communities: one in its core region in central Brazil (Brasília, DF) and the other on its southern periphery (Itirapina, SP). We contrasted the length of the dry season, soil fertility rates, leaf concentrations of $\mathrm{N}, \mathrm{P}, \mathrm{K}, \mathrm{Ca}$ and $\mathrm{Mg}$ and the specific leaf area (SLA) between these communities. The dry season was shorter on the periphery, where the soil was more fertile although more acidic. Plants from the periphery showed higher SLA and higher leaf concentrations of $\mathrm{N}, \mathrm{P}, \mathrm{Ca}$ and $\mathrm{Mg}$. We propose that the higher SLA of plants from the periphery is related to the shorter dry season, which allows better conditions for nutrient uptake.
\end{abstract}

Key words: savanna, mineral nutrition, rainfall seasonality, specific leaf area.

\section{INTRODUCTION}

Savannas occupy $20 \%$ of emerged lands (Sankaran et al. 2005), covering $21 \%$ of the Brazilian territory (Souza and Habermann 2012), 25\% of the Australian

Correspondence to: Marcelo Claro de Souza E-mail: marcelo.claro.souza@gmail.com territory (Williams et al. 2005) and 40\% of Africa's land area (Okitsu 2005). Savannas are composed of grasses, shrubs and trees, and the function and structure of species are strongly influenced by ecological filters (Gottsberger and SilberbauerGottsberger 2006). For instance, fire frequency, 
soil fertility, water availability and herbivory have been recognized as important ecological filters in savannas (Sankaran et al. 2005).

Soil nutrient uptake and leaf development are water-dependent (Kreuzwieser and Gessler 2010). In fact, leaf traits such as nutritional status and the specific leaf area (SLA, e.g. proportion of leaf area unit of leaf mass) have been regularly used to explain responses of savanna species to variations in ecological filters. In Australian savannas, species growing on poor soils and subjected to high frequency of fire and droughts possess decreased concentrations of nutrients in their leaves, which tend to be more sclerophyllous (low SLA). In contrast, species growing on fertile soils with low frequency of drought and fire show nutrient-rich and less sclerophyllous leaves (Wright et al. 2001, Prior et al. 2005). Although there are some indications that changes in nutrient availability affects leaf nutrient status and SLA of cerrado species (Bucci et al. 2006, Delgado et al. 2013), detailed studies at the community level are lacking.

The Cerrado domain is very large ( $\sim 2$ millions $\mathrm{km}^{2}$ ), and similar vegetation physiognomies occur in areas with distinct water availability (Gottsberger and Silberbauer-Gottsberger 2006) and may grow on soils from different geological formations (Motta et al. 2002). Thus, the structure and functioning of different cerrado plant communities could vary considerably due to variations in water and nutrient availability in these soils.

Considering that cerrado sensu stricto communities located in the core and on the southern periphery of its domain are subjected to soils with different geological formations and fertility, and to different seasonalities, we tested the hypothesis that variations in SLA and leaf nutritional status between both communities are connected to the length of the dry season and soil fertility. After all, these are important differences empirically noted between such locations and there is some evidence that the length of the dry season might affect leaf nutritional status of cerrado species (Bustamante et al. 2012). We expect the plants on the southern periphery to be less sclerophyllous and retain more nutrients in their leaves in comparison to plants from the core, where soils appear to be poorer and the dry season, longer.

\section{MATERIALS AND METHODS}

\section{SITE AND STUDY DESCRIPTION}

The study was conducted in two cerrado sensu stricto fragments, one in the core region and the other on the southern periphery of the Cerrado domain. In the core of the Cerrado, the plant community was located at the Ecological Reserve of IBGE (15 ${ }^{\circ} 57^{\prime} \mathrm{S}$ $47^{\circ} 52^{\prime} \mathrm{W}$ ) in Brasília, the Brazilian Federal District. On the periphery, the plant community was growing on the São José da Conquista farm $\left(22^{\circ} 13\right.$ 'S $\left.47^{\circ} 53^{\prime} \mathrm{W}\right)$, in Itirapina, São Paulo state. Both sites present rainy summers and dry winters.

A 30-year-dataset was used to estimate the mean annual rainfall, length of the dry and wet seasons and air temperature, from 1980 to 2010 (Walter 1986). The climatic data were provided by the National Institute of Meteorology (INMET 2013). Total annual rainfall in the core is about 1452 $\mathrm{mm}$ and the mean annual temperature, about $21^{\circ} \mathrm{C}$. On the periphery, total annual rainfall is $1512 \mathrm{~mm}$ and mean annual temperature near $20^{\circ} \mathrm{C}$ (Fig. 1).

We studied 15 woody species in the core and 21 species on the southern periphery (Table I). In both communities, three plots of $15 \times 15 \mathrm{~m}$ were established and only species that were common among plots were selected. The plants were sampled between February and March 2005 (in the core; Araújo 2006) and 2011 (on the periphery). Soil sampling was also performed in the three plots.

\section{SPECIFIC LEAF AREA AND Nutritional Status}

Fully expanded mature leaves were sampled from 4-6 plants per species, according to the availability. The leaves were washed with deionized water and oven-dried at $60^{\circ} \mathrm{C}$ until constant mass to avoid $\mathrm{N}$ losses (Souza et al. 2015). 

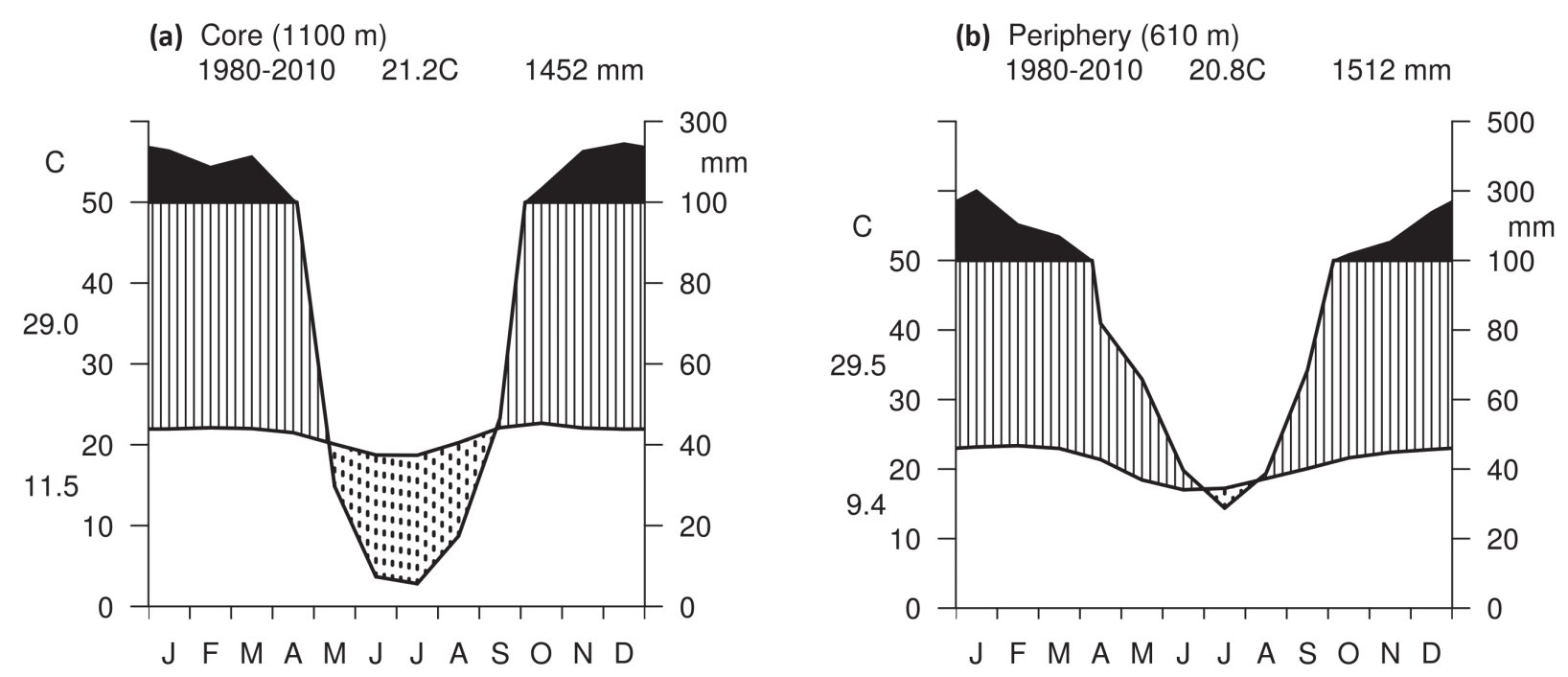

Figure 1 - Walter climatic diagram displaying the length of the dry and wet seasons, elevation, annual rainfall and air temperature and monthly averages for a period of 30 years (1980-2010) in the core (a) and southern periphery (b) of the Cerrado.

To determine the specific leaf area (SLA), six leaves perplant of each species were used for obtaining 40 leaf discs of pre-determined area ( $1 \mathrm{~cm}$ of diameter). The SLA was calculated as the ratio between leaf area $\left(\mathrm{cm}^{2}\right)$ and leaf dry mass $(\mathrm{g})$ (Habermann and Bressan 2011). Leaves from both communities were digested in an acid solution (nitric:percloric) and leaf $\mathrm{N}$ concentration was determined by the micro-Kjeldahl method. For the core's community, the concentration of $\mathrm{Ca}, \mathrm{Mg}$ and $\mathrm{K}$ were determined by atomic absorption spectrophotometry and $\mathrm{P}$ was measured colorimetrically (Allen 1989). For the periphery's community, leaf concentrations of $\mathrm{Ca}$ and $\mathrm{Mg}$ were determined by atomic absorption spectrophotometry, $\mathrm{K}$ was determined using a flame photometer, and $\mathrm{P}$ was determined colorimetrically (Sarruge and Haag 1974, Dantas and Batalha 2011). SLA and nutrient leaf status was measured and computed as per species. However, to test our hypothesis and for statistical reasons we combined every species from each plant community and analyzed them together.

\section{SOIL CHARACTERIZATION}

Soil samples were randomly collected $(0-30 \mathrm{~cm}$ in depth) from each of the three plots. Chemical parameters $[\mathrm{pH}, \mathrm{N}$, organic matter $(\mathrm{OM}), \mathrm{P}, \mathrm{K}, \mathrm{Ca}$, $\mathrm{Mg}$ and $\mathrm{Al}]$ and physical properties (percentage of clay, silt and total sand) were determined according to Raij et al. (1987). Procedures are described in English in Dantas and Batalha (2011).

\section{DATA ANALYSIS}

The variations in $\mathrm{pH}, \mathrm{OM}, \mathrm{P}, \mathrm{K}, \mathrm{Ca}, \mathrm{Mg}$ and $\mathrm{Al}$ in the soils and the variations in leaf concentrations of $\mathrm{N}, \mathrm{P}, \mathrm{K}, \mathrm{Ca}$ and $\mathrm{Mg}$, and also in SLA between both communities were analyzed using a multivariate analysis of variance MANOVA at 5\% level. We used a standardized major axis (SMA) regression to test for significant differences in slopes and intercepts between leaf concentrations of $\mathrm{N} x \mathrm{P}, \mathrm{Ca}$ x Mg, SLA x N, and SLA x P (Warton et al. 2006) for both communities. We performed the statistical procedures in R (R Development Core Team 2012).

\section{RESULTS}

\section{Climate AND SoIl CHARACTERIZATION}

Both regions exhibited similar total annual rainfall and average temperature, but the dry season on the peripheral community was not 
TABLE I

List of species selected from two cerrado sensu stricto communities located in the core and on the southern periphery of the Cerrado.

\begin{tabular}{|c|c|c|c|}
\hline Family & Specie & Site & Leaf deciduousness* \\
\hline Annonaceae & Annona coriacea Mart. & Periphery & EG \\
\hline Annonaceae & Xylopia aromatica (Lam.) Mart. & Periphery & EG \\
\hline Apocynaceae & Aspidosperma tomentosum Mart. & Periphery & $\mathrm{D}$ \\
\hline Araliaceae & Schefflera paniculata Elmer & Core & EG \\
\hline Calophyllaceae & Kielmeyera coriacea Mart. & Core & $\mathrm{D}$ \\
\hline Caryocaraceae & Caryocar brasiliensis A.St.-Hil. & Core/Periphery & $\mathrm{BD} / \mathrm{D}$ \\
\hline Erythroxylaceae & Erythroxylum suberosum A.St.-Hil. & Periphery & $\mathrm{BD}$ \\
\hline Erythroxylaceae & Erythroxylum tortuosum Mart. & Periphery & $\mathrm{BD}$ \\
\hline Erythroxylaceae & Erythroxylum pelleterianum A.St.-Hil. & Periphery & $\mathrm{D}$ \\
\hline Fabaceae & Sclerolobium paniculatum Vogel & Core & EG \\
\hline Fabaceae & Dalbergia miscolobium Benth. & Core & $\mathrm{BD}$ \\
\hline Fabaceae & Stryphnodendron adstringens (Mart.) Coville & Core & $\mathrm{BD}$ \\
\hline Malpighiaceae & Byrsonima crassa Nied. & Core & $\mathrm{BD}$ \\
\hline Malpighiaceae & Byrsonima basiloba A.Juss. & Periphery & EG \\
\hline Malpighiaceae & Byrsonima intermedia A.Juss. & Periphery & EG \\
\hline Malpighiaceae & Banisteriopsis variabilis B.Gates & Periphery & $\mathrm{D}$ \\
\hline Malvaceae & Eriotheca gracilipes (K.Schum.) A.Robyns & Periphery & $\mathrm{D}$ \\
\hline Melastomataceae & Miconia pohliana Cogn. & Core & EG \\
\hline Melastomataceae & Miconia rubiginosa (Bonpl.) A.DC. & Periphery & EG \\
\hline Melastomataceae & Miconia fallax DC. & Periphery & EG \\
\hline Myrsinaceae & Rapanea umbellata Mart. & Periphery & EG \\
\hline Myrtaceae & Blepharocalyx salicifolius (Kunth) O.Berg & Core & $\mathrm{BD}$ \\
\hline Myrtaceae & Myrcia bella Cambess. & Periphery & $\mathrm{BD}$ \\
\hline Nyctaginaceae & Guapira noxia (Netto) Lundell & Core & $\mathrm{D}$ \\
\hline Nyctaginaceae & Guapira opposita (Vell.) Reitz & Periphery & $\mathrm{BD}$ \\
\hline Ochnaceae & Ouratea hexasperma Baill. & Core & EG \\
\hline Rubiaceae & Tocoyena formosa (Cham. \& Schltdl.) K.Schum. & Periphery & $\mathrm{D}$ \\
\hline Salicaceae & Casearia sylvestris Swartz & Periphery & $\mathrm{BD}$ \\
\hline Sapotaceae & Pouteria torta (Mart.) Radlk. & Periphery & EG \\
\hline Styracaceae & Styrax ferrugineus Nees \& Mart. & Periphery & $\mathrm{BD}$ \\
\hline Vochysiaceae & Vochysia elliptica Mart. & Core & EG \\
\hline Vochysiaceae & Vochysia thyrsoidea Pohl & Core & EG \\
\hline Vochysiaceae & Qualea grandiflora Mart. & Core/Periphery & $\mathrm{D} / \mathrm{BD}$ \\
\hline Vochysiaceae & Qualea parviflora Mart. & Core & $\mathrm{D}$ \\
\hline
\end{tabular}

*Leaf deciduousness of cerrado senso stricto species from plant communities in the core (Araújo 2006) and on the southern periphery (Souza et al. 2015) of the Cerrado. EG - evergreen, BD - brevideciduous, D - deciduous.

only shorter (July-August) but also milder, while in the core the dry season was longer (May September) and more severe (Fig. 1).

The soil from the periphery was more acidic $(\mathrm{pH}<4.0)$ although richer in $\mathrm{N}, \mathrm{P}, \mathrm{Ca}$ and $\mathrm{Mg}$ in comparison to the soil from the core (Table II). In addition, the soil from the core showed higher percentages of clay and silt. The Al saturation $(\mathrm{m} \%)$ and $\mathrm{K}$ and $\mathrm{OM}$ concentrations did not differ between the sites (Table II).

\section{LEAF TRAITS}

The plant community located on the southern periphery of the Cerrado domain showed higher 
leaf concentrations $\left(\mathrm{g} \mathrm{kg}^{-1}\right)$ of $\mathrm{N}(18.22 \pm 8.05), \mathrm{P}$ (1.06 \pm 0.34$), \mathrm{Ca}(5.33 \pm 1.97)$, and $\mathrm{Mg}(1.96 \pm 0.72)$ in comparison to the plant community in the core region: $\mathrm{N}(14.36 \pm 7.46), \mathrm{P}(0.64 \pm 0.24), \mathrm{Ca}(3.71 \pm$ 2.78), and $\mathrm{Mg}(1.34 \pm 0.66)$ (Fig. 2).
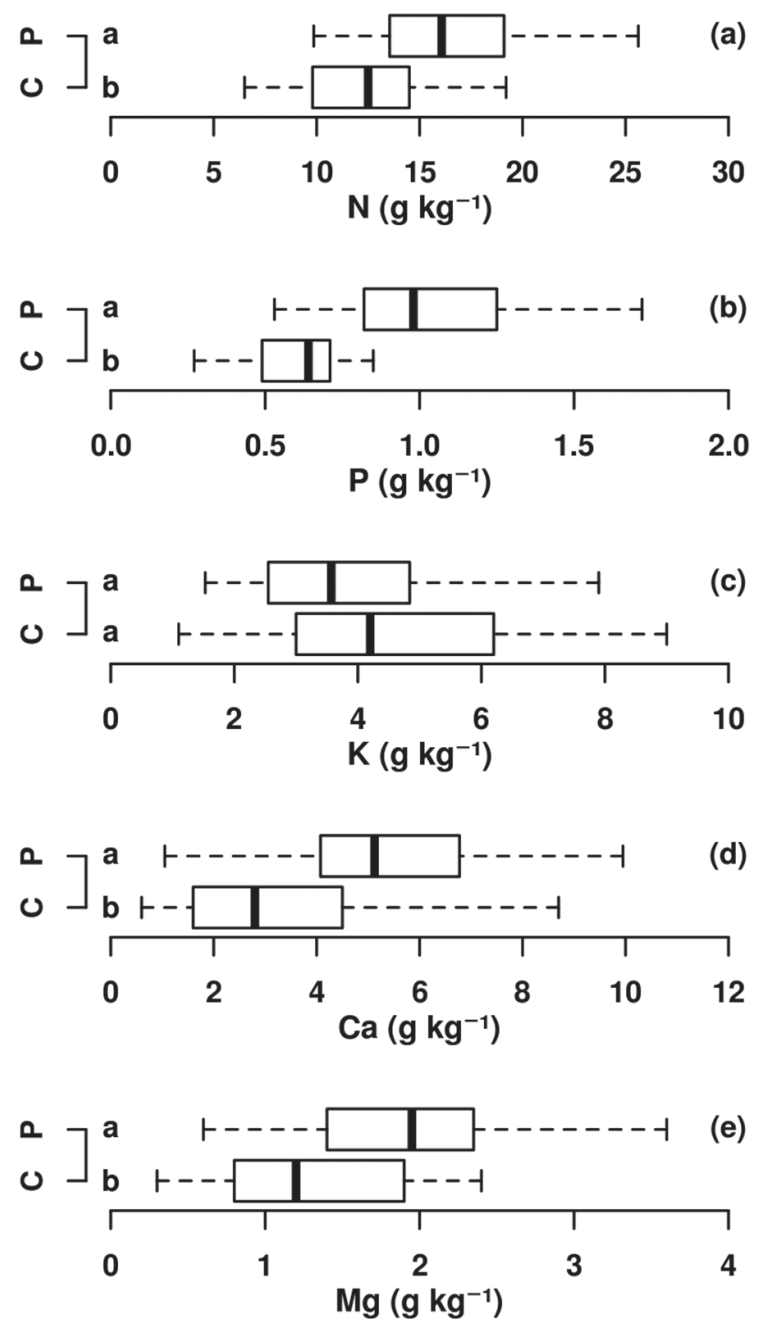

Figure 2 - Box plots showing leaf nutrient concentration [nitrogen (a), phosphorus (b), potassium (c), calcium (d) and magnesium (e)] in two cerrado sensu stricto communities located in the core and southern periphery of the Cerrado. The line in the middle of each box indicates the $50^{\text {th }}$ percentile of the observed distribution; the left and right parts of each box represent the $25^{\text {th }}$ and $75^{\text {th }}$ percentiles, respectively; the left and right error bars of each box are the $5^{\text {th }}$ and the $95^{\text {th }}$ percentiles of the observed distribution. Different letters indicate significant difference $(\mathrm{p}<0.05)$ using a multivariate analysis of variance (MANOVA) at 5\% level between the core (C) and the southern periphery (P) of the Cerrado.
TABLE II

Soil properties of two cerrado sensu stricto communities in the core and on the southern periphery of the Cerrado.

\begin{tabular}{lccc}
\hline \multirow{2}{*}{ Soil parameter } & \multicolumn{2}{c}{ Site } & \multirow{2}{*}{ P value } \\
\cline { 2 - 3 } & Core & Periphery & \\
\hline $\mathrm{pH}\left(\mathrm{CaCl}_{2}\right)$ & $4.6 \pm 0.2$ & $3.9 \pm 0.1$ & $<0.001$ \\
Organic matter $\left(\mathrm{g} \mathrm{dm}^{-3}\right)$ & $28.3 \pm 0.4$ & $20.7 \pm 2.4$ & 0.138 \\
$\mathrm{~N}(\%)$ & $0.14 \pm 0.2$ & $0.17 \pm 0.3$ & $<0.001$ \\
$\mathrm{P}\left(\mathrm{mg} \mathrm{dm}^{-3}\right)$ & $1.6 \pm 0.4$ & $2.2 \pm 0.3$ & 0.031 \\
$\mathrm{~K}\left(\mathrm{mmol}_{\mathrm{c}} \mathrm{dm}^{-3}\right)$ & $1.0 \pm 0.5$ & $1.3 \pm 0.2$ & 0.298 \\
$\mathrm{Ca}\left(\mathrm{mmol}_{\mathrm{c}} \mathrm{dm}^{-3}\right)$ & $0.2 \pm 0.2$ & $1.9 \pm 0.5$ & 0.001 \\
$\mathrm{Mg}\left(\mathrm{mmol}_{\mathrm{c}} \mathrm{dm}^{-3}\right)$ & $0.3 \pm 0.4$ & $1.1 \pm 0.2$ & 0.011 \\
$\mathrm{Al}\left(\mathrm{mmol}_{\mathrm{c}} \mathrm{dm}^{-3}\right)$ & $8.5 \pm 2.4$ & $13.4 \pm 1.5$ & 0.013 \\
$\mathrm{Al} \mathrm{saturation}(\mathrm{m} \%)$ & $85.4 \pm 8.1$ & $75.9 \pm 3.3$ & 0.07 \\
$\mathrm{Clay} \%$ & $65.4 \pm 6.9$ & $13.2 \pm 0.8$ & $<0.001$ \\
Sand \% & $19.7 \pm 4.3$ & $84.5 \pm 1,2$ & $<0.001$ \\
Silt \% & $14.2 \pm 2.8$ & $2.3 \pm 0.6$ & 0.001 \\
\hline
\end{tabular}

The plant community on the periphery exhibited higher SLA values $\left(125.56 \pm 38.14 \mathrm{~cm}^{2} \mathrm{~g}^{-1}\right)$ than those exhibited by plants in the core $(69.01 \pm$ 20.41) (Fig. 3). There were positive correlations between leaf concentration of $\mathrm{N}$ and P (Fig. 4a), and between $\mathrm{Ca}$ and $\mathrm{Mg}$ (Fig. 4b) for both communities. Significant differences between plant communities were observed in the $\mathrm{N} x$ P relationship due to the significant variation in the intercepts (Fig. 4a).

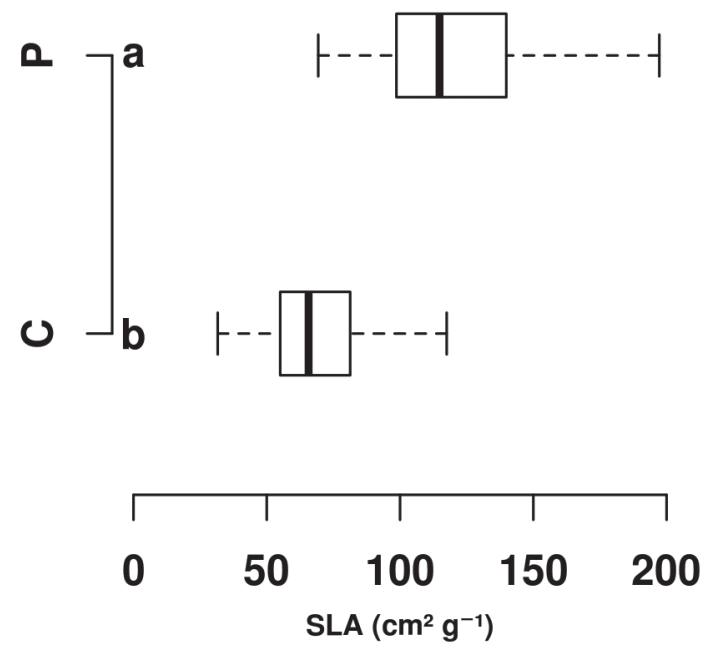

Figure 3 - Box plots of specific leaf area (SLA) in cerrado sensu stricto communities located in the core (C) and on the southern periphery $(\mathrm{P})$ of the Cerrado. Box plot characteristics are as described in Figure 2. 

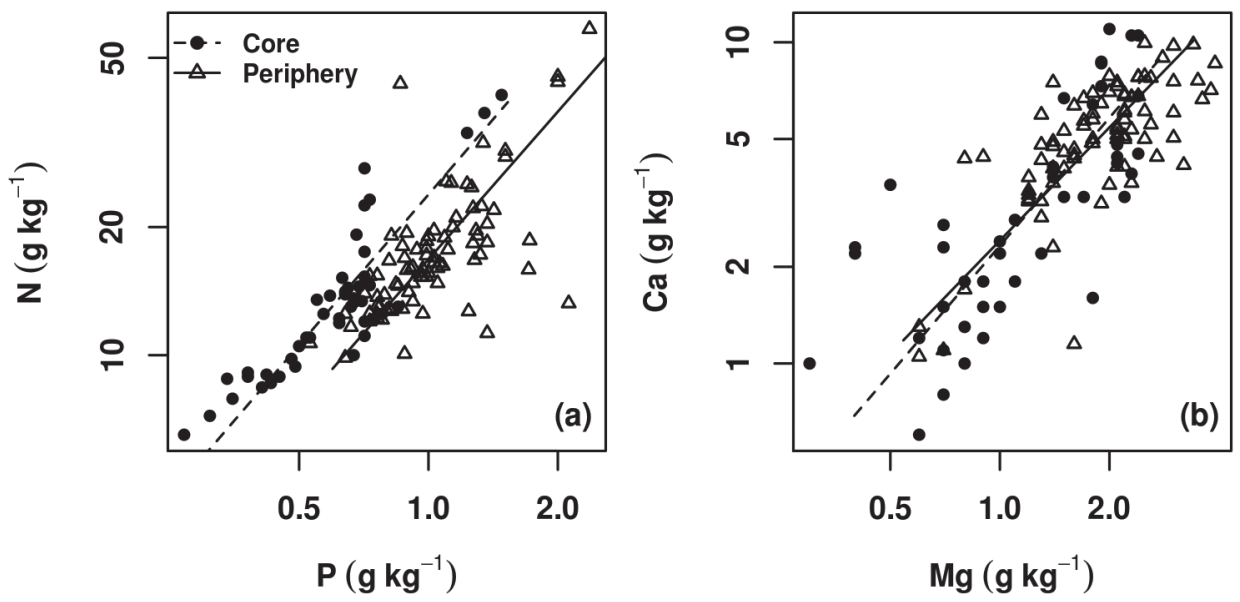

Figure 4 - Standardized major axis (SMA) relationships between leaf concentrations of $\mathrm{N}$ versus $\mathrm{P}$ $\left(\right.$ core $-\mathrm{p}<0.001, \mathrm{R}^{2}=0.772$, intercept $=1.378$, slope $=1.776$; periphery $-\mathrm{p}<0.001, \mathrm{R}^{2}=0.451$, intercept $=1.225$, slope $=1.153)$ (a) and Ca versus $\mathrm{Mg}\left(\right.$ core $-\mathrm{p}<0.001, \mathrm{R}^{2}=0.549$, intercept $=0.367$, slope $=$ 1.324; periphery $-\mathrm{p}<0.001, \mathrm{R}^{2}=0.535$, intercept $=0.383$, slope $\left.=1.170\right)$ (b) for two cerrado sensu stricto communities in the core and on the southern periphery of the Cerrado. Axes are $\log 10$ scaled.

However, for the $\mathrm{Ca} \times \mathrm{Mg}$ relationship, there was no significant variation either for intercept or for elevation between both communities. In addition, we found no clear relationship between SLA x N (Fig. 5a) or between SLA x P (Fig. 5b).

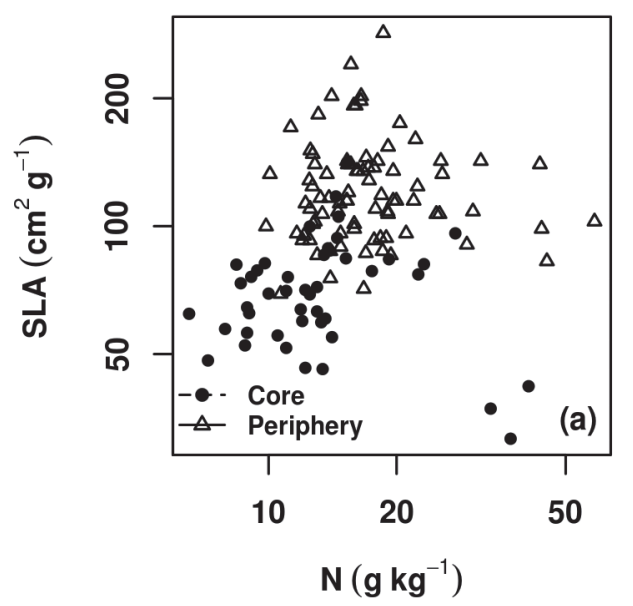

\section{DISCUSSION}

The total annual rainfall in the core $(\sim 1450 \mathrm{~mm})$ was nearly the same as the periphery $(\sim 1500 \mathrm{~mm})$ and these rainfall values are enough to support forest vegetation in the tropics (Gottsberger and

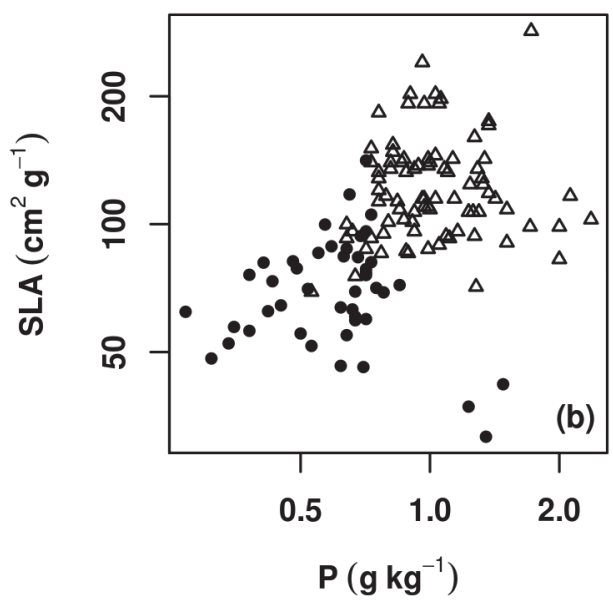

Figure 5 - Standardized major axis (SMA) relationships between leaf concentrations of N x SLA $(p>0.05)$ and P x SLA ( $>0.05)$ for two cerrado sensu stricto communities in the core $(C)$ and on the southern periphery $(\mathrm{P})$ of the Cerrado. Axes are $\log 10$ scaled. 
Silberbauer-Gottsberger 2006, Silva et al. 2013). Rather than similar annual rainfall between the sites, we observed and highlight a significant difference in the length of the dry season between the communities ( 2 months on the periphery and approximately 5 months in the core).

Savanna species from wet regions are less sclerophyllous (show high SLA) than species from dry regions, which tend to have low SLA (Wright et al. 2001, Prior et al. 2005). Indeed, this is true only for savannas where the total annual rainfall and the length of the dry season are negatively correlated (M.C. Souza et al., unpublished data). For example, in the Australian savanna, rainfall decreases from the north of the country toward the center, while the length of the dry season shows the opposite pattern. In this scenario, SLA gets higher as going to the north region (Prior et al. 2005 for references). For Neotropical savannas, such as the cerrado, there is no clear relationship between annual rainfall and the length of the dry season (Gottsberger and Silberbauer-Gottsberger 2006). In fact, the length and severity of the dry season is much more variable than the total annual rainfall, which is similar across most of the Cerrado region (Gottsberger and Silberbauer-Gottsberger 2006).

For plants, in general, water deficit not only affects leaf structure, but may also impair plant growth and development by restricting plant transpiration and thus soil nutrient uptake (Chaves et al. 2002). For cerrado plants it may also occur (Prado et al. 2004), and the dry season reduces soil nutrient uptake and, consequently, the amount of soil-derived nutrients available to be deployed in new leaves (Kreuzwieser and Gessler 2010). We observed that the peripheral plant community showed higher leaf $\mathrm{N}$ concentration and SLA in comparison to the plant community from the core, suggesting low scleromorphism on the southern peripheral community. Association between high soil $\mathrm{N}$ availability and low leaf scleromorphism was already observed for some cerrado species (Delgado et al. 2013). A significant correlation between SLA and N was observed in studies comparing Australian savannas under different soil fertilities and rainfall regimes (Wright et al. 2001), and when comparing congeneric species from savanna and forest environments in Brazil (Hoffmann et al. 2005). In the present study, we did not observe significant SLA x N correlations for any of the two communities, suggesting that this relationship is not conserved for all savanna physiognomies.

Leaf scleromorphism has also been used to discriminate between forest and savanna species. Forest species are less sclerophyllous (have high SLA) than savanna species (Hoffmann et al. 2005) since the main limitation in forests is the capture of sunlight (Givnish 1988, Habermann and Bressan 2011), while in savannas the main challenge is surviving the dry season (Prado et al. 2004, Bucci et al. 2008). Less sclerophyllous species invest more in photosynthetic tissues, have higher ratios of mesophyll to epidermis, and mesophyll to leaf thicknesses (Delgado et al. 2013, Somavilla et al. 2014); moreover, these species accumulate more $\mathrm{N}$, $\mathrm{P}, \mathrm{Ca}$ and $\mathrm{Mg}$ in their leaves on a leaf mass basis (Hoffmann et al. 2005).

Low $\mathrm{pH}$, high $\mathrm{Al}$ concentration and low fertility are typical characteristics of cerrado soils (Haridasan 2008), but within cerrado areas, soils may vary regarding $\mathrm{pH}$ and fertility rates (Cianciaruso et al. 2013). In the core, the soil is less fertile and less acidic although it presents similar Al saturation $(\mathrm{m} \%)$ in relation to the soil from the southern periphery. Soil Ca concentration was ten times greater on the periphery in relation to the core, and plants from the periphery retained more nutrients in their leaves, including $\mathrm{Ca}$.

On the periphery, soils are younger and less leached than soils from the core (Motta et al. 2002), and we noted that the dry season is shorter on the southern periphery. Therefore, the annual rainfall seems to be better distributed on the periphery, providing better conditions for nutrient uptake and accumulation in leaves. In contrast, the long 
dry season in the core (Fig. 1) may impair plant growth, nutrient uptake and accumulation. These associations support the hypothesis that leaf scleromorphism and the nutritional status of the cerrado sensu stricto plant communities may not reflect solely the soil fertility where these plants grow, but also that the length of the dry season may play an important role on the structure and functioning of these communities.

\section{CONCLUSIONS}

Our results support the hypothesis that plants on the southern periphery are less sclerophyllous and retain more nutrients in their leaves in comparison to the core region. This illustrates that similar vegetation physiognomies within the Cerrado domain can differ in leaf functional traits. Based on 30-year data sets of climatic data, and on measurements of soil fertility and leaf traits, we propose that rather than total rainfall, the length of the dry season may be an important cause of variation of leaf traits, determining structural differences between plant communities of the same physiognomies.

\section{ACKNOWLEDGMENTS}

MCS acknowledges the Coordenação de Aperfeiçoamento de Pessoal de Nível Superior (CAPES) and the Fundação de Amparo à Pesquisa do Estado de São Paulo (FAPESP) for $\mathrm{PhD}$ fellowships (grants \#2010/07809-1 and BEPEFapesp \#2012/13762-3). Authors acknowledge Capes and the German Academic Exchange Service (DAAD), the PROBAL-CAPES DAAD project (360/11) for the financial support to the exchange of researchers (Annette Menzel, GH, and LPCM) and students (MCS) between Brazil and Germany. The field study in São Paulo was supported by FAPESP (grants \#2007/59779-6 and FAPESPVALE grant \#2010/51307-0). ACF, GH and LPCM acknowledge the Conselho Nacional de Desenvolvimento Científico e Tecnológico (CNPq) for research productivity fellowships. We thank Dr. Annette Menzel, Dr. Garry D. Cook and Dr. Neal W. Menzies for valuable comments on early versions of the manuscript. We are also grateful to Katharine Carroll (The University of Queensland) for the English review.

\section{RESUMO}

Apesar das limitações nutricionais e elevada acidez dos solos, a flora do cerrado é a mais rica entre as savanas. Muitas espécies lenhosas do cerrado possuem folhas escleromórficas e o nível de escleromorfismo foliar parece depender da disponibilidade de água e nutrientes no solo. Visando um melhor entendimento sobre a estrutura e funcionalidade da vegetação do cerrado, foram comparadas duas comunidades de cerrado sensu stricto: uma na região central do Brasil (Brasília, DF) e a outra na periferia sul (Itirapina, SP). Para tal, comparamos a duração da estação seca, a fertilidade do solo, as concentrações foliares de N, P, K, Ca e Mg e a área foliar específica (AFE) entre as duas comunidades do cerrado. A estação seca na periferia foi menor em relação à região central, e seu solo foi considerado mais fértil e mais ácido. A vegetação periférica apresentou maior AFE e apresentou maiores concentrações foliares de N, P, Ca e Mg. Baseado nestes resultados, propomos que a maior AFE observada na comunidade periférica se deve à menor duração da estação seca, a qual possibilita melhores condições para absorção de nutrientes do solo.

Palavras-chave: savana, nutrição mineral, precipitação, área foliar específica.

\section{REFERENCES}

ALLEN SE. 1989. Chemical analysis of ecological materials. Blackwell Scientific Publications, Oxford.

ARAÚJO JF. 2006. Padrões nutricionais de espécies lenhosas do cerrado. Master dissertation, Universidade de Brasília. (Unpublished).

Bucci SJ, Scholz FG, Goldstein G, Meinzer FC, Franco AC, CAMPanello PI, Villalobos-Vega R, Bustamantes M AND Miralles-WiLhelm FM. 2006. Nutrient availability constrains the hydraulic architecture and water relations of savannah trees. Plant Cell Environ 29: 2153-2167. 
Bucci SJ, Scholz FG, Goldstein G, Meinzer FC, Franco AC, ZHANG Y AND HAO G. 2008. Water relations and hydraulic architecture in Cerrado trees: adjustments to seasonal changes in water availability and evaporative demand. Braz J Plant Physiol 20: 233-245.

Bustamante MMC, Nardoto GB, Pinto AS, Resende JCF, TAKAHASHI FSC AND VIEIRA LCG. 2012. Potential impacts of climate change on biogeochemical functioning of Cerrado ecosystems. Braz J Biol 72: 655-671.

Chaves MM, Pereira JS, Maroco J, Rodrigues ML, RICARDO CPP, OSÓRIO ML, CARVALHO I, FARIA T AND PINHEIRO C. 2002. How plants cope with water stress in the field. Photosynthesis and growth. Ann Bot 89: 907-916.

CiancIaruso MV, SiLVA IA, MANICA LT AND SOUZA JP. 2013. Leaf habit does not predict leaf functional traits in cerrado woody species. Basic Appl Ecol 14: 404-412.

DANTAS VL AND BATALHA MA. 2011. Vegetation structure: Fine scale relationships with soil in a cerrado site. Flora 206: 341-346.

Delgado MN, GOMES MRA, BÁo SN AND RosSATTO DR. 2013. Fertilisation residues alter leaf scleromorphy in an evergreen savannah shrub (Maprounea brasiliensis, Euphorbiaceae). Aust J Bot 61: 266-273.

GIVNISH TJ. 1988. Adaptation to sun and shade: a whole plant perspective. Aust J Plant Physiol 15: 63-92.

GotTsberger G AND Silberbauer-GotTSBerger I. 2006. Life in the Cerrado, a South American Tropical Seasonal Ecosystem. Vol. 1. Origin, Structure, Dynamics and Plant Use (Reta Verlag, Ulm, Germany).

HABERMANN G AND BRESSAN ACG. 2011. Root, shoot and leaf traits of the congeneric Styrax species may explain their distribution patterns in the cerrado sensu lato areas in Brazil. Funct Plant Biol 38: 209-218.

HARIDASAN M. 2008. Nutritional adaptations of native plants of the cerrado biome in acid soils. Braz J Plant Physiol 20: 183-195.

HOFFMANN WA, Franco AC, MOREIRA MZ AND HARIDASAN M. 2005. Specific leaf area explains differences in leaf traits between congeneric savanna and forest trees. Funct Ecol 19: 932-940.

INMET. 2013. Available: http://www.inmet.gov.br/portal/. Accessed 10 October 2013.

KREUZWIESER J AND GESSLER A. 2010. Global climate change and tree nutrition: influence of water availability. Tree Physiol 30: 1221-1234.

MOTTA PEF, CURI N AND FRANZMEIER DP. 2002. Relation of soils and geomorphic surfaces in the Brazilian Cerrado. In: Oliveira PS and Marquis RJ (Eds), The Cerrados of Brazil: ecology and natural history of a neotropical savanna. Chicago, Columbia University Press, p. 13-32.
OKITSU S. 2005. Factors controlling geographical distribution in savanna vegetation in Namibia. Afri Stud Mono 30(Suppl.): 135-151.

Prado CHBA, Wenhui Z, Rojas MHC And SouZa GM. 2004. Seasonal leaf das exchange and water potential in a woody cerrado species community. Braz J Plant Physiol 16: 7-16.

PRIOR LD, BOWMAN DMJS AND EAMUS D. 2005. Intra-specific variation in leaf attributes of four savanna tree species across a rainfall gradient in tropical Australia. Aust J Bot 53: 323-335.

R Development Core TeAm. 2012. R: a language and environment for statistical computing. $\mathrm{R}$ foundation for statistical computing, Vienna. URL: http://www.r-project.org.

Raij B, Quaggio JA, Cantarella H, Ferreira ME, Lopes AS AND BATAGLIA OC. 1987. Análise química do solo para fins de fertilidade. Fundação Cargill, Campinas, 170 p.

SANKARAN M ET AL. 2005. Determinants of woody cover in African savannas. Nature 438: 846-849.

SARRUGE JR AND HAAG HP. 1974. Análises químicas em plantas. Piracicaba, ESALQ, 54 p.

SILVA CR, HOFFMANN WA, RosSATO DR, HARIDASAN M, FRANCO AC AND HoRWARTH WR. 2013. Can savanna become forests? A coupled analysis of nutrient stock and fire thresholds in central Brazil. Plant Soil 373: 829-842.

SOMAVILla NS, KolB RM AND RosSATTO DR. 2014. Leaf anatomical traits corroborate the leaf economic spectrum: a case study with deciduous forest tree species. Braz J Bot 37: 69-82.

SOUZA MC, BuENO PCP, MORELlato LPC AND HABERMANN G. 2015. Ecological strategies of Al-accumulating and non-accumulating functional groups from the cerrado sensu stricto. An Acad Bras Cienc 87: 813-823.

SouzA MC AND HABERMANN G. 2012. Towards a new ecophysiological approach to understand citrus crop yield under abiotic stresses mirroring in the Brazilian savanna genetic resources. In: Rahman IMM and Hasegawa H (Eds), Water Stress. Rijeka: InTech, p. 152-164.

WALTER H. 1986. Vegetação e zonas climáticas. EPU, São Paulo, 326 p.

WARTON DI, WRIGHT IJ, FALSTER DS AND WeStBoy M. 2006. Bivariate line-fitting methods for allometry. Biol Rev 81: 259-291.

Williams RJ, CARTER J, DufF GA, Woinarski JCZ, COOK GD AND FARRER SL. 2005. Carbon accounting, land management, science and policy uncertainty in Australian savanna landscapes: introduction and overview. Aust J Bot 53: 583-588.

Wright IJ, REICH PB AND WeStoBy M. 2001. Strategy shifts in leaf physiology, structure and nutrient content between species of high-and-low-rainfall and high and low-nutrient habitats. Func Ecol 15: 423-434. 
